a

\title{
The death of a medieval Danish warrior. A case of bone trauma interpretation
}

\author{
Eva Forsom ${ }^{1, *}$, Lene Warner Thorup Boel ${ }^{1}$, Bo Jaque², Lene Mollerup ${ }^{3}$
}

\author{
1 Department of Forensic Medicine, Aarhus University, Palle Juul-Jensens Boulevard 99, 8200 Aarhus N, Denmark \\ ${ }^{2}$ Muserum Skive, Brårupgade 18, 7800 Skive, Denmark \\ ${ }^{3}$ Museum Skanderborg, Munkevej 8, 8680 Ry, Denmark \\ *E-mail: eforsom@forens.au.dk
}

\begin{abstract}
:
In 1934 a grave was found in the church ruins of the Cistercian Abbey at Øm in central Jutland, Denmark (founded in 1172, demolished 1561 AD). The grave contained the skeletal remains of an individual lying in a supine position with the head towards the west. The anthropological analysis revealed that the remains belonged to a young male, aged 25-30 years at death and approximately 162.7 $\mathrm{cm}$ tall. He had 9 perimortem sharp force lesions, five of which were cranial and four were postcranial, indicating he suffered a violent death in a swordfight.

This paper presents a detailed analysis and description of the individual lesions and their probable effect on the soft tissue, followed by a suggestion for the most likely order of the blows which caused the lesions, and finally a tentative reconstruction of the battle accompanied by photographs. This case illustrates both that forensic pathology can be very useful when applied to an archaeological case and suggests that the forensic pathologist could benefit from examination of ancient cases when interpreting bone lesions in modern cases.
\end{abstract}

Keywords:

Forensic anthropology, bone lesions, medieval Denmark, warfare, swordfight, battle reconstruction, sharp force trauma

\section{INTRODUCTION}

The study of trauma in skeletal remains is important to bioarchaeology as it can provide insight into the patterns of interpersonal violence and warfare in the past, an important aspect of human society [1]. Studies of weapon related trauma from medieval Europe have mostly focused on mass graves or burial sites containing many individuals [2-7] but smaller assemblages of one or just a few individuals with interesting cases of perimortem trauma have also been published [8-10] All of these contribute with valuable information on the mechanisms of warfare in pre-modern populations. With an in-depth knowledge of traumatological principles and an advanced understanding of biomechanics of injury the forensic pathologist contributes to relevant interpretation of pathoanatomy of skeletons in collaboration with archaeological specialists.

The abbey at $\varnothing m$ is located in a rural area in the central part of the Danish Jutland peninsula and was founded in 1172 by Cistercian monks from Vitskøl Abbey in northern Jutland. The monks named the monastery Cara Insula, which means "the beloved isle" [11] and the early years of the abbey are described in the preserved handwritten Chronicle of Øm, Exordium Monasterii Carae Insulae, which recounts the events of the years from 1207 to 1267 [12]. The abbey was in use until the $16^{\text {th }}$ century [13]. The ruins at $\varnothing m$ have been thoroughly excavated in the 20th century. Altogether, 668 skeletons from a total of 921 graves have been excavated and recorded throughout the years, although not all of them were stored afterwards due to poor preservation [14]. Osteological analysis was originally conducted by K. Isager in the 1930s [15].

This paper focuses on a single case of a male individual whose grave was discovered in 1934 . We present a detailed description of the lesions identified on the skeleton and propose a manner of violent death.

\section{MATERIAL AND METHODS}

The grave and skeletal material

The grave of skeleton 4.X.1 was discovered under the floor of the church. The skeleton was in a supine position with the head towards the west. A large, wedge-shaped bone fragment was missing from the forehead but later found inside the skull. The mouth was wide open and the shoulders were pressed together as if the body had been wrapped tightly in a shroud before burial (Figure 1). The lower arms were folded above the pelvis and the legs were stretched out (A. Andersen. 1933-1934. Unpublished notebook, Øm Abbey Museum).

The grave and the skeletal remains inside cannot be dated precisely as there were no finds in the grave to indicate the date of the burial but the context can be used to give a rough estimate of the timeframe. The abbey church was in use in the period from approximately 1257 to 1561 [12] The positioning of the arms in the grave, folded across the lap, indicates that the individual was buried between 1250 and 1350, as arm placement is a commonly used, if somewhat controversial, indicator of the time of burial within the medieval period in Scandinavia [16]. Modern archaeological investigations tentatively date the western gable, which was built after the main church was finished, to the 14th or early 15th Century, although this is only a rough estimate [17]. The grave was later cut by another grave, resulting in the removal of the feet, which makes it the earliest grave of the two based on stratigraphy. 


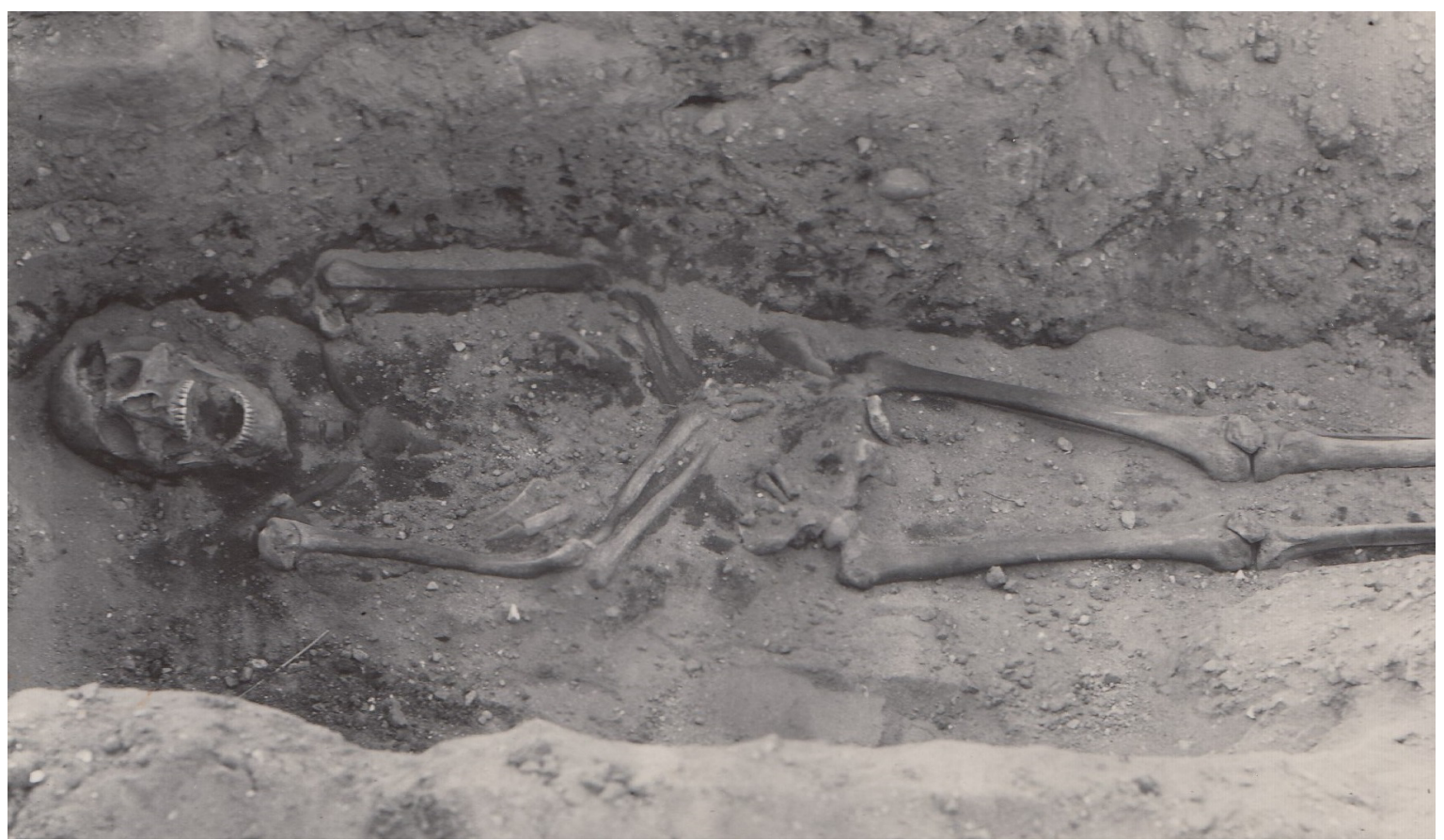

Figure 1: The grave of skeleton 4.X.1 (a male individual discovered in 1934 during excavations at the medieval Danish site of Øm Abbey) with the skeleton in a supine position. A large, wedge-shaped injury to the skull is visible with the bone fragment later found inside the skull. The mouth is wide open and the shoulders are pressed together. Photo: Øm Abbey Museum, 1934

\section{Osteological methods}

Although the skeleton had originally been examined and analysed by K. Isager [15], sex, age and trauma were re-analysed in 2008 using up to date, standard osteological and forensic methods $[18,19]$. Stature was calculated from the length of the femur (average of the right and left side), based on the equation presented in Lynnerup et al. [21], p. 101, which was developed for Danish medieval skeletons by Boldsen [20], making it the most appropriate method to use on the skeleton from Øm based on time period and population. The skeletal lesions were then examined at the Department of Forensic Medicine, Aarhus University. The parts of 4.X.1 displaying trauma which is discussed in this article: the skull, left radius, left ulna and both tibiae, are now exhibited at the Øm Abbey Museum, while the rest of the skeleton is stored at the Unit of Anthropology, Department of Forensic Medicine, University of Southern Denmark (ADBOU).

\section{RESULTS}

The skeletal remains belonged to a young adult male, aged between 25 to 30 years at death. He was approximately $162.7 \mathrm{~cm}(+/-4.31 \mathrm{~cm})$ tall and of a normal to slender build (Right femur: $44.7 \mathrm{~cm}$, left femur: $45.5 \mathrm{~cm}$, average: $45.1 \mathrm{~cm}$, right tibia: $37.5 \mathrm{~cm}$, left tibia: $37.3 \mathrm{~cm}$ ). The bones of the skeleton have nine lesions, five cranial (Figures 2-4) and 4 postcranial (Figure 5), with no signs of healing and fractures consistent with fresh bone breakage, indicating they were inflicted perimortem [22] and all of them had typical characteristics of sharp force trauma [23]. The directions of the inflicted lesions are given with the body in an anatomically normal position as is the standard. The body could have been in any other possible position when the lesions were inflicted.

\section{Cranial lesions}

Lesion 1(Figure 6) is an $11 \mathrm{~cm}$ long sharp force trauma on the left side of the frontal and parietal bones. The blow was directed from above and downwards/inwards. The lesion continues anteriorly as a fracture line running from the front of the frontal bone towards the glabella and posteriorly as a fracture line perpendicular to the lesion, running across the left and right frontal bone, then making an oblique turn and terminating at the edge of the right upper orbit. From the middle of the first fracture line is another fracture running through the right parietal bone shaped like an upside down "V" towards the back of the head and terminating in the lambdoid suture. The great impact of this lesion removed some bone fragments from the frontal bone above the glabella and from the left parietal bone.

Lesion 2 (Figure 6) is a $4 \mathrm{~cm}$ long sharp force trauma to the left side of the frontal bone and the parietal bone, starting $5.5 \mathrm{~cm}$ in front of the posterior part of the first lesion and from this a $5 \mathrm{~cm}$ long fracture line runs towards the upper left orbit. The blow was directed obliquely from above and inwards/ slightly downwards.

The combination of lesion 1 and 2 resulted in a wedge-shaped bone fragment $10 \times 4.5 \mathrm{~cm}$ breaking off just behind the coronal suture.

Lesion 3 (Figure 7) is a $4.4 \mathrm{~cm}$ long sharp force trauma on the back of the left parietal bone, parallel with the first lesion but approximately $3 \mathrm{~mm}$ displaced from it. The direction of the blow is almost straight forwards, then inwards and downwards.

Lesion 4 (Figure 7) is a $3.5 \mathrm{~cm}$ long superficial sharp force lesion on the middle of the left parietal bone $1.5 \mathrm{~cm}$ medial to and parallel with the third lesion, directed forwards and inwards/downwards.

Lesion 5 (Figure 8) is an approximately $6 \mathrm{~cm}$ long sharp force lesion towards the lower and posterior part of the left parietal bone. The angle of 


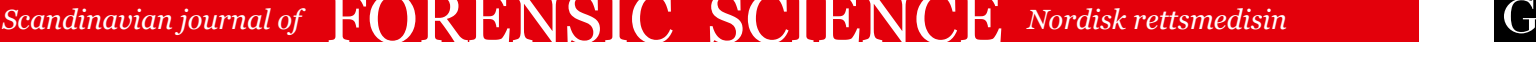

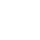

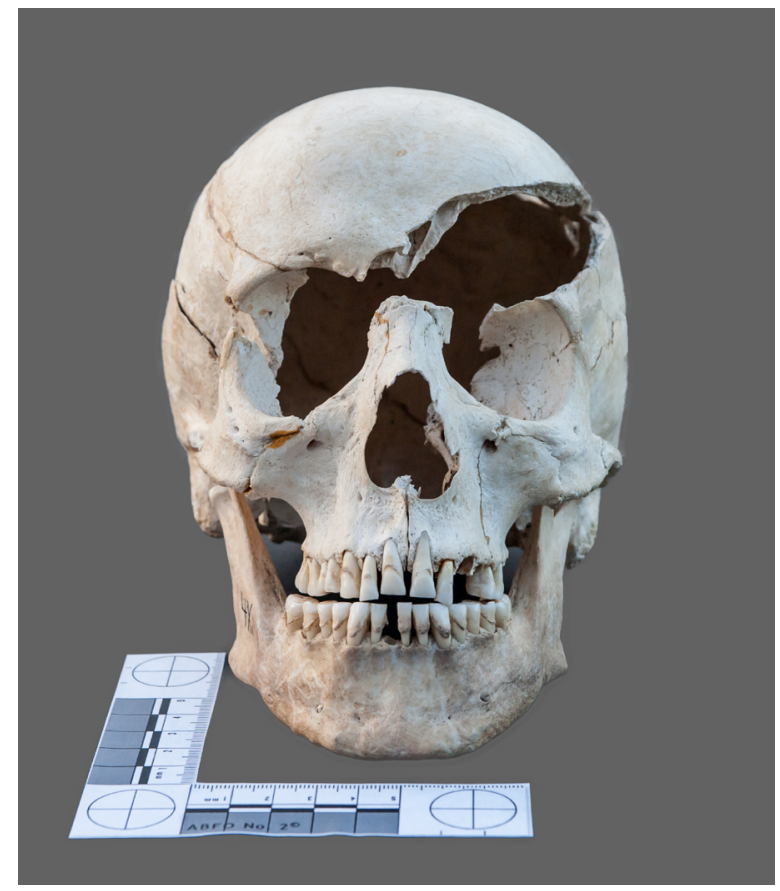

Figure 2: The cranium seen from the front. Photo: Susan Kipp Pedersen.

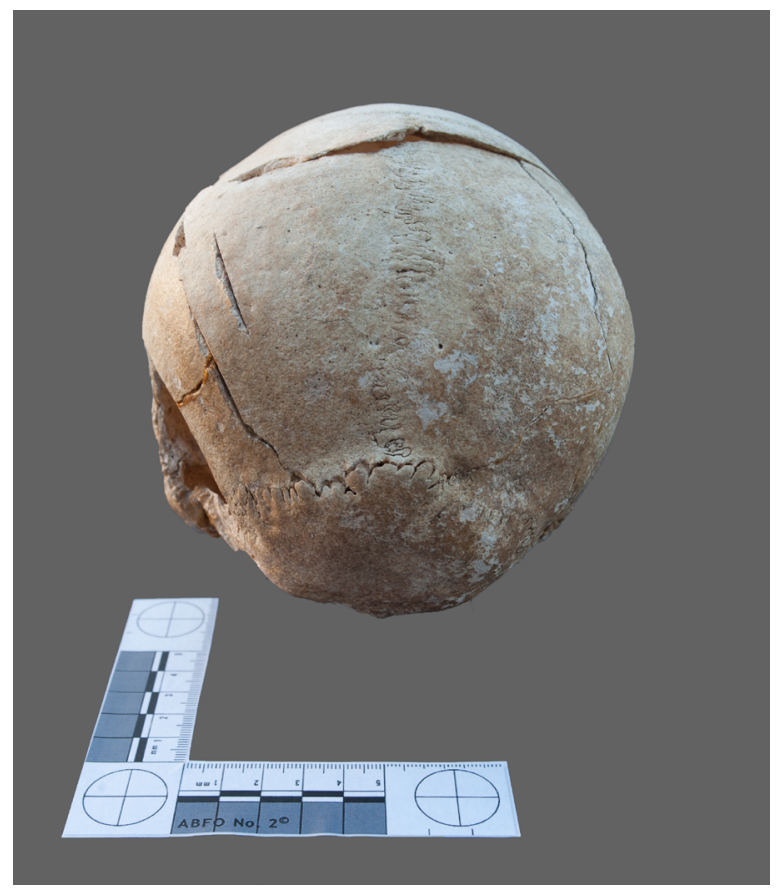

Figure 3: The cranium seen from behind. Photo: Susan Kipp Pedersen.
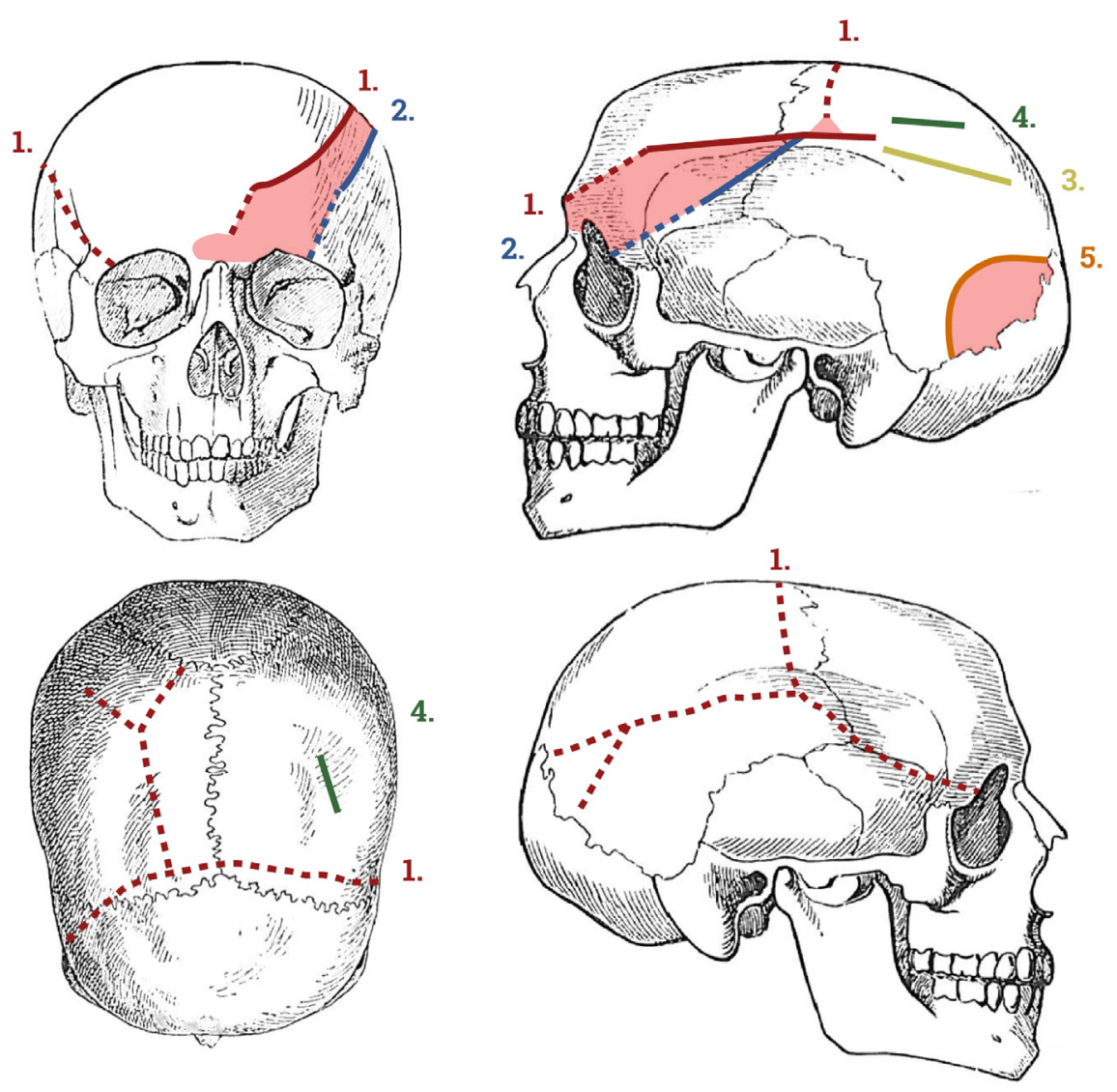

Figure 4: Diagram showing the distribution of the cranial injuries. Each lesion has a different color. Solid lines indicate sharp force trauma, dashed lines are fracture lines and the filled-in areas indicate break-off. Graphics: Kristine Hedensten, Museum Skanderborg. 


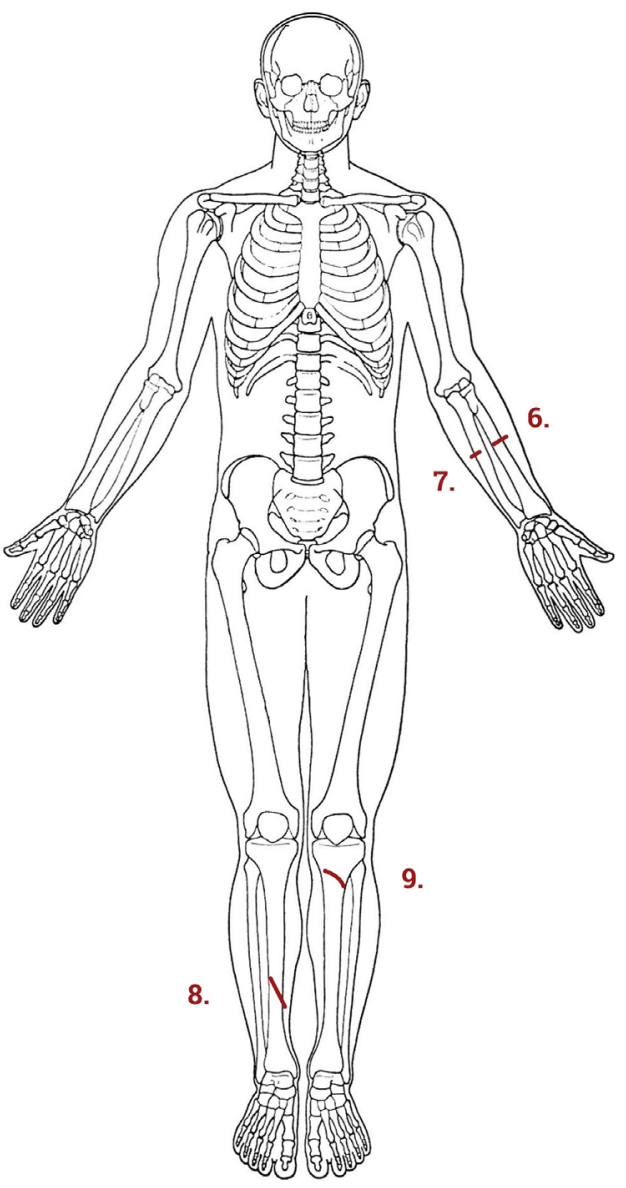

Figure 5: Diagram showing the distribution of the postcranial injuries. Graphics: Kristine Hedensten, Museum Skanderborg.

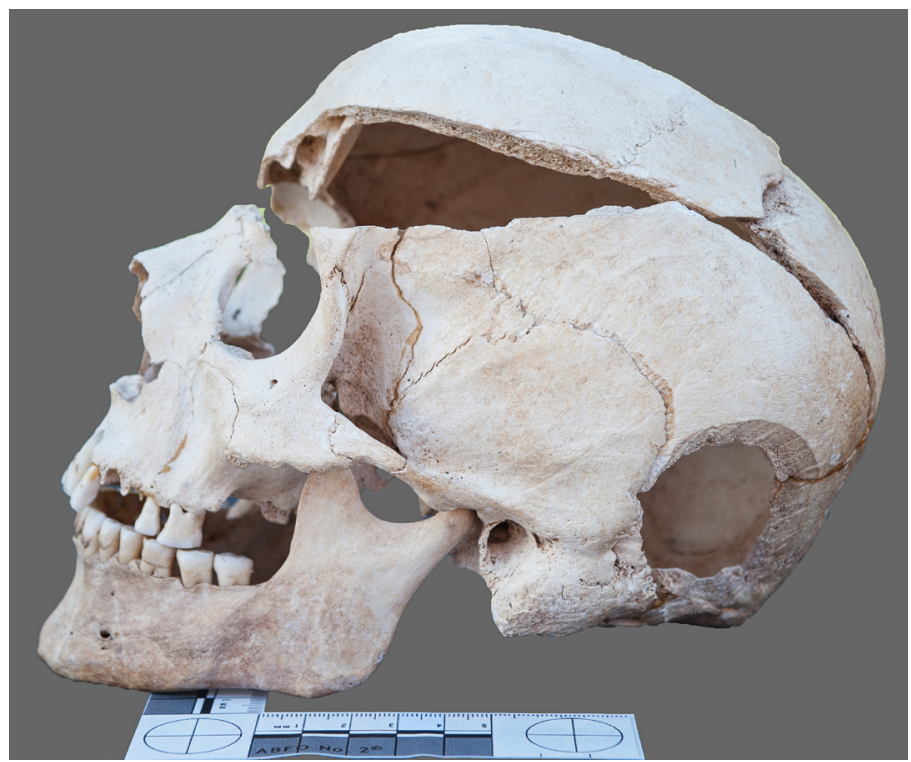

Figure 6: The cranium seen from the left side, showing Lesions 1 and 2 at the top/center and Lesion 5 on the lower right. Photo: Susan Kipp Pedersen.

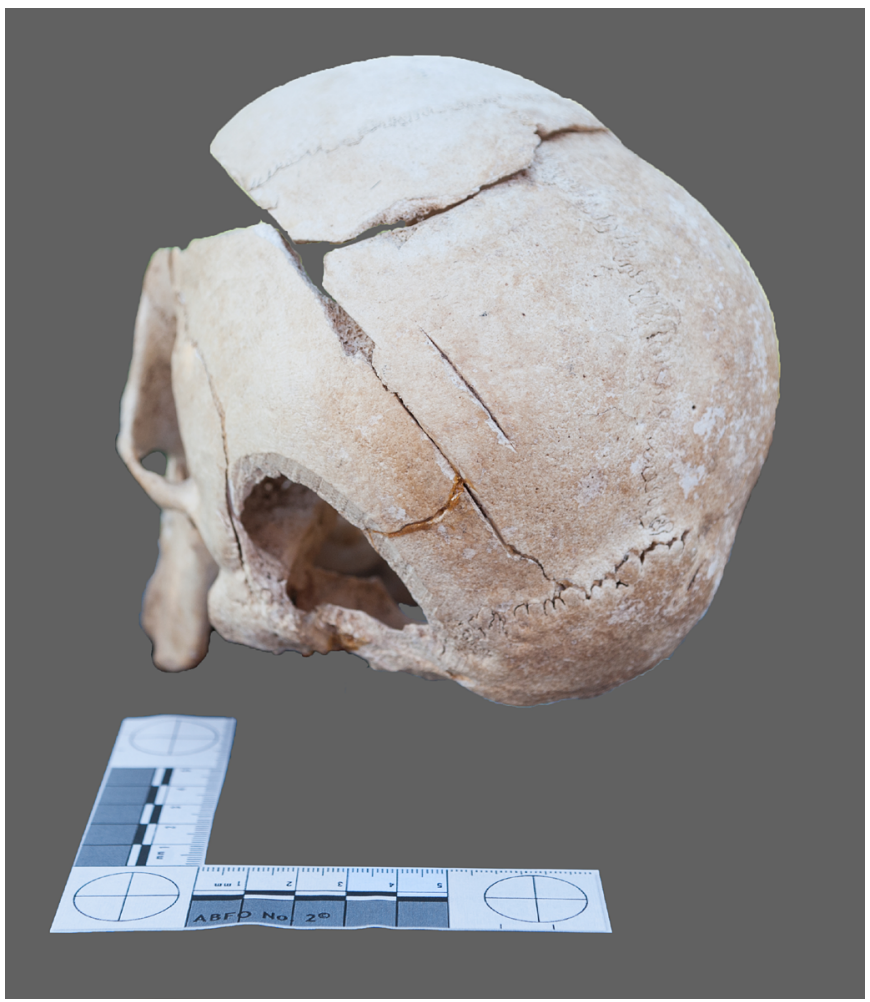

Figure 7: The left side of the cranium seen from a superoposterior angle, showing Lesions 3 and 4 in the center and with Lesions 1,2 and 5 visible to the left. Photo: Susan Kipp Pedersen.

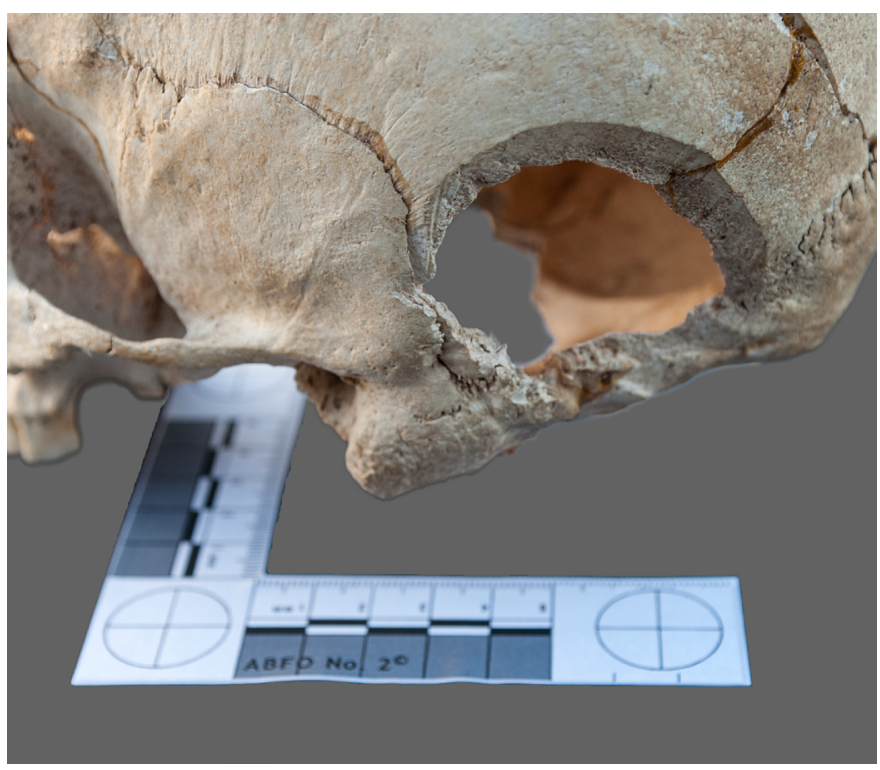

Figure 8: Lesion 5, a sharp force trauma to the lower posterior part of the left parietal bone. Photo: Susan Kipp Pedersen. 
(a)

the lesion is forward and downward and slightly inwards towards the midline. The lesion has led to a rounded piece of the parietal bone (approximately $5 \times 6 \mathrm{~cm}$ ) breaking off inferiorly.

\section{Postcranial lesions}

Lesion 6 is a $9 \mathrm{~mm}$ long and $4 \mathrm{~mm}$ deep sharp force lesion on the back of the left radius, approximately $11 \mathrm{~cm}$ beneath the proximal joint. The blow came obliquely from above.

Lesion 7 on the back of ulna is a $6 \mathrm{~mm}$ long transverse superficial sharp lesion, located $14 \mathrm{~cm}$ beneath acromion on the same level as Lesion 6 and caused by the same blow.

Lesion 8 (Figure 9) is located on the anteromedial side of the right tibia approximately $25 \mathrm{~cm}$ from the proximal end of the bone. The lesion is a $3 \mathrm{~cm}$ long sharp force lesion which was struck from a medial, downwardly inclined direction. The lesion cuts through the cortical bone to the medullary cavity and a $2.5 \times 1 \mathrm{~cm}$ large bone piece is broken off lateral to the lesion.

Lesion 9 is a $2.6 \mathrm{~cm}$ long sharp force trauma on the anterior side of the left tibial tuberosity, approximately $3 \mathrm{~cm}$ from the proximal end of the bone. The lesion is laterally and downwardly inclined, cutting through the cortical bone. On the medial side, the lesion continues in a $4 \mathrm{~cm}$ long fracture line that penetrates the cortical bone.

\section{Lesion Summary}

In summary, all lesions were inflicted by sharp edged weapons with considerable force, and are compatible with sword cuts. On the skull, lesion 1 was inflicted before lesion 2, and lesion 3 was inflicted before the lesion 5 . The lesions 1 and 2, and 5 (Figure 6 and Figure 8) are all lethal lesions that could all have caused intracranial hemorrhage and momentary loss of consciousness. Lesions 3 and 4, and 5 (Figure 7 and Figure 8) were caused by a strike from the posterior, moving in an anterior, downwards and inwardly inclined direction, while the blows causing lesions 1 and 2 were struck from an anterosuperior position moving downwards and inwards towards the midline. Lesion 6 and 7 are typical defensive lesions but could also have been inflicted in battle while holding both hands raised in a striking position. These lesions have cut through skin, muscles and smaller blood vessels and the nerves of the wrist and fingers. The blow that inflicted lesion 8 (Figure 9) would have cut through skin, muscles, tendons and smaller blood vessels and possibly the tibial artery. The strike that resulted in lesion 9 penetrated the skin and most likely severed the patellar tendon. The lesions 6 and 7 on the lower arm and the lesions 8 and 9 on the lower legs were probably inflicted before the lethal lesions to the skull.

\section{Reconstruction of the battle}

Most often a warrior would aim his strikes towards those areas of the body that would inflict most immediate injury and/or reduce the opponent's probability of a counterattack. In this case, the legs would probably have been the most vulnerable areas (less protected) and the location of the injuries on the lower extremities most likely reduced the warrior's capabilities of combat significantly. Following these initial injuries, the fatal injuries were consequently delivered to the head. Based on the findings a reconstruction of the warrior's fight is presented in Figure 10 and described below. It is important to note that this is only an interpretation of the order of the blows. It is not possible to ascertain whether or not all the lesions were by a single person and/or weapon.

The injury on the lower left leg shows that a slash has come from above and continued downwards. The sword tip probably only touched the bone but the blow resulted in the patella tendon being cut through and as a result the man would have lost mobility (Figure 10a). He might have been able to stand up afterwards but he would have had difficulties bending and lifting the leg. In the midst of battle, this would have been a calamitous situation. On the right lower leg the slash came likewise from the top but when the sword was removed, the power from the blade separated a piece of bone from the tibia. This cut could have caused massive bleeding as the lesion possibly destroyed the artery of the lower leg (Figure 10b). Normally there would have been several injuries to the arms and hands during a sword fight

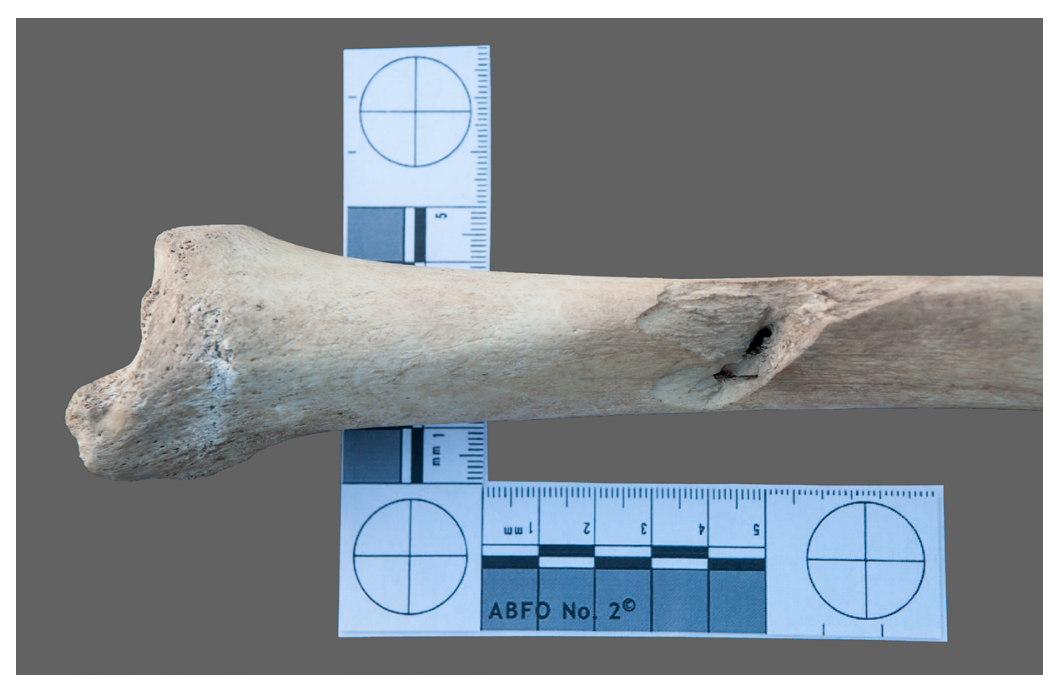

Figure 9: Lesion 8, a sharp force trauma to the anteromedial side of the right tibia. Photo: Susan Kipp Pedersen. 

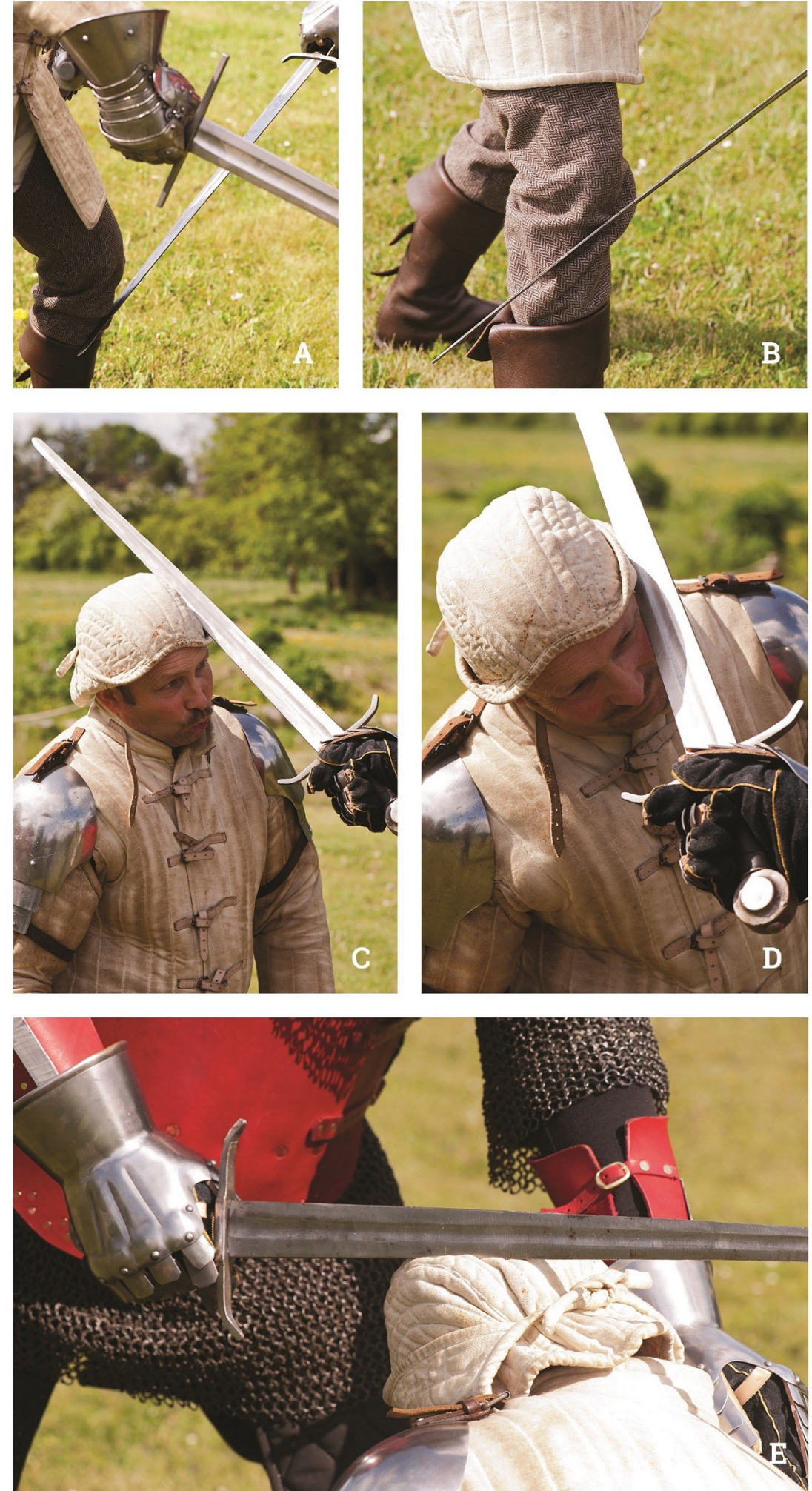

Figure 10: Reconstruction of the battle. A: The blow to the lower left leg that caused Lesion 9; B: Lesion 8 was caused by a blow to the lower right leg; C: Lesion 1 was caused by a lethal blow to the left side of the forehead; D: Another lethal blow was struck close to Lesion 1 but lower, resulting in Lesion 2; E: There were three lesions on the back of the skull but only Lesion 5 was lethal, caused by a blow striking behind the left ear. Photo: Ib Nikolajsen, Museum Skanderborg. 
because these body parts are closest to the opponent. But on this victim there is only one. It is assumed that a blow towards a lower arm of an adult man without any protection would have resulted in amputation of the arm. So possibly the man had some kind of body protection that helped reduce the impact of the blow. The trauma to the left lower arm is $4 \mathrm{~mm}$ deep and would had damaged veins and nerves as well as inflicted some blood loss. As a result of this, he would not have been able to bend his hand backwards and probably been unable to stretch his fingers. The largest impact of the battle is the lesions to the skull where three out of five lesions were lethal. The most significant lesion is lesion 1 that has cut the left side of the forehead, imbedding the blade approximately $3 \mathrm{~cm}$ into the brain and caused serious damage to the front of the brain. The impact from this blow resulted in a significant skull fracture that runs across the top of the skull and ends up on the other side at the right orbit (Figure 10c). Lesion 2 hit the same area of the skull at the first lesion, but the lesion is situated lower and has a different angle. The lesion that starts on the left temple above the left ear has split the front of the skull down towards the left orbit (Figure 10d). This blow was also lethal and the two lesions all together resulted in a wedge shaped part of the skull was breaking loose. On the back of the skull are three lesions. Two of them have only penetrated the skin and made minor cut marks on the skull. These lesions were not lethal, whereas lesion 5 that cut away a piece off the back of the head behind the left ear was lethal on its own (Figure 10e).

\section{DISCUSSION}

Although the identity is unknown, the multiple injuries on 4.X.1 suggest that he was a warrior or at least that he died in battle. He was one of 30 individuals from Øm Abbey, 26 males and 4 of unidentified sex, who had traumatic lesions to the skull or body caused by blunt or sharp weapons. A total of $5.7 \%$ of all males buried at the Abbey had trauma to the skull inflicted by violence, most often found on the left side of the skull. Six males displayed postcranial injuries and three of these, including 4.X.1, also had skull injuries [24]. The lesions from 4.X.1 were all sword cuts. The sword was the most distinguished weapon in the Middle Ages and legendary as the master weapon of the nobility. It was an effective weapon and the normal medieval blade was approximately 80 to $90 \mathrm{~cm}$ long, usually sharp on both sides and designed for full forced blows towards an opponent. In the early and high Middle Ages the sword was not common among foot soldiers and presumably the sword owners were mostly from the upper echelons of the feudal society, mainly knights and squires. The individual examined sustained nine lesions that could be identified, of which five were to the skull and the remainder to the axial end peripheral skeleton. Skeletal findings from medieval battlefields clearly show that most blows were aimed towards the head and the extremities, with the legs being the most affected limbs at Visby [2] and Uppsala [5]. This must be the logical consequence from the time where the body protection mainly covered the torso (shield and armour), whereas the head and legs were often uncovered. Normally one would expect a right handed attacker to hit his opponent on the left side of the body and skull and on the remains from the Battle of Visby, more of the cranial injuries were on the left side compared to the right, although there were blows from all directions [2]. On the remains from other medieval battlefields like those of Næstved [6], Uppsala [5] and Towton [7], the cranial injuries clearly show that the blows came from all angles and directions and, like at Visby [2], that multiple injuries to the same individual were common. This might indicate that the warriors have been involved in battle under great turmoil without an actual structure. From the injuries identified on the bones from 4.X.1 it is possible to speculate what kind of battle he died in. He was most likely a trained swordsman who had experience in the use of weapons, and he was probably fighting like his opponent with a sword in a war-like situation or in a local feud with several warriors on both sides. Presumably some kind of armour was covering his body and he probably used some sort of additional protection, like a shield. The first injuries he sustained were probably the lesions on the lower legs and arm. These types of lesions weakened his ability to fight aggressively and to protect himself. In the final phase of the battle, he received the first lethal blow to the skull (Lesion 1) allowing the blade to penetrate $3 \mathrm{~cm}$ into the brain, leaving him with an intracerebral lesion, intracranial hemorrhage and momentary loss of consciousness. The next blow probably fell within seconds and slid into his skull even before his body started to collapse. It is possible that the second blow was inflicted to make sure he was neutralized. Immediately after, he fell to the ground, possibly with the opponent holding on to his right shoulder to end the battle with a kill. The smaller cut marks to the back of the head and the open lesion behind the left ear are less specific and may have been inflicted as he was on his way down or when he was already lying on the ground. After his death, the body was removed from the battlefield and transferred to the Abbey of $Ø \mathrm{~m}$ for burial. His body was probably wrapped tight in a shroud. The skeleton was found buried in a coffin at the back of the church (A. Andersen. 1933-1934. Unpublished notebook, Øm Abbey Museum), which indicates some kind of relation to the monastery as a burial in a Cistercian church in the Middle Ages was not granted to just anybody. Hence, the individual 4.X.1 was probably a member of the local or regional elite whereby his family could afford to pay for his burial inside the church. While we will never know the identity of the warrior, the careful attention to and evaluation of his injuries and burial context does provide interesting insights into burial practices and warfare in Medieval Denmark. The field of archaeology benefits greatly from the expertise of the forensic pathologist. Moreover, the forensic pathologist can get experience in interpretation of lesions on modern persons by examining ancient bones. This could be useful, as the forensic pathologist can use this experience when interpreting modern homicide cases or victims from mass graves and genocide, as it has sadly been seen from the last decades. 


\section{REFERENCES}

[1] Knüsel C., Smith M., In: Knüsel C., Smith M.J. (Eds.) Introduction. The bioarchaeology of conflict, The Routledge Handbook of the Bioarchaeology of Human Conflict, Routledge, Oxon, 2014, 3-24

[2] Ingelmark B.E., The skeletons, In: Thordeman B. (Ed.), Armour from the battle of Wisby 1361, Kungliga Vitterhets historie och antikvitets akademien, Stockholm, 1939, 149-209

[3] Stroud G., Kemp R.L., Cemeteries of the Church and Priory of St Andrew, Fishergate, Council for British Archaeology, York, 1993

[4] Cunha E., Silva A.M., War lesions from the famous Portuguese Medieval Battle of Aljubarrota, International Journal of Osteoarchaeology, 1997, 7, 595-599

[5] Kjellström A., A Sixteenth-Century Warrior Grave from Uppsala, Sweden: the Battle of Good Friday, International Journal of Osteoarchaeology, 2005, 15, 23-50

[6] Bennike P., Rebellion, combat and massacre: a medieval mass grave at Sandbjerg near Næstved in Denmark, In: Otto T., Thrane H., Vandkilde H. (Eds.), Warfare and Society, Aarhus University Press, Aarhus, 2006, 305-318

[7] Novak S.A., 2007. Battle-related trauma, In: Fiorato V., Boylston A., Knüsel C. (Eds.), Blood Red Roses. The Archaeology of a Mass Grave from the Battle of Towton AD 1461, Oxbow Books, Oxford, 90-102

[8] Facchini F., Rastelli S., Belcastro M.G., Peri mortem cranial injuries from a medieval grave in Saint Peter's Cathedral, Bologna, Italy, International Journal of Osteoarchaeology, 2008, 18, 421-430

[9] Giuffra V., Pejrani Baricco L., Subbrizio M., Fornaciari G., Weapon-related cranial lesions from medieval and Renaissance Turin, Italy, International Journal of Osteoarchaeology, 2013, 27, 690-700

[10] Appleby J., Rutty G.N., Hainsworth S.V., Woosnam-Savage R.C., Morgan B., Brough A., Earp R.W., Robinson C., King T.E., Morris M., Buckley R., Perimortem trauma in King Richard III: a skeletal analysis, The Lancet, 2015, 385, 253-259

[11] McGuire B.P., Conflict and Continuity at Øm Abbey. A Cistercian Experience in Medieval Denmark, Museum Tusculanum, Copenhagen, 1976

[12] Olrik J., Isager J., Garner H.N. (trans.), Øm klosters krønike, Scriptorium, Øm Kloster Museum, Skanderborg, 1997
[13] Garner H.N., Øm kloster museum, Scriptorium (Ry Bogtryk, Rex), Ry, 1998

[14] Mollerup L., Begravelser ved Øm Kloster, In: Gregersen B., Jensen C.S. (Eds.), Øm Kloster. Kapitler af et middelalderligt cistercienserabbedis historie, Syddansk Universitetsforlag, Odense, 2003, 145-164

[15] Isager K., Skeletfundene ved Øm Kloster. Cara Insula MCLXXII - MDLX.Til Belysning af middelalderlig Patologi og Klosteret som Hospital, Levin \& Munksgaard, København, 1936

[16] Kieffer-Olsen J., Grav og gravskik i det middelalderlige Danmark, Afd. For Middelalderarkæologi og Middelalderarkæologisk nyhedsbrev, Højbjerg, 1993

[17] Kristensen H.K., Klosterkirken i Øm. Vejledning til danske kirker 8, Forlaget Hikuin, Højbjerg, 2011

[18] Buikstra J.E., Ubelaker D.H., Standards for data collection from human skeletal remains, Arkansas Archeological Survey Research Series no. 44, Fayetteville, 1994

[19] Lynnerup N., Bennike P., Iregren E. (Eds.), Biologisk Antropologi med human osteologi, Gyldendal, København, 2008

[20] Boldsen J.L., Population structure, body proportions and height prediction, Adli Tıp Dergisi, 1990, 6, 157-165

[21] Lynnerup N., Petersen H.C., Alexandersen, V. Antropometri, In: Lynnerup N., Bennike P., Iregren E. (Eds.), Biologisk Antropologi med human osteologi, Gyldendal, København, 2008, 97-110

[22] Sauer N., The timing of injuries and manner of death: distinguishing among antemortem, perimortem, and postmortem trauma, In: Reichs K. (Ed.), Forensic Osteology Advances in the Identification of Human Remains, 2nd ed., Charles C. Thomas, Springfield, 1998, 321-332

[23] Kimmerle E.H., Baraybar J.P., Skeletal trauma. Identification of injuries resulting from human rights abuse and armed conflict. Taylor \& Francis Group: CRC Press, Boca Raton, 2008

[24] Mollerup L., Begravelserne ved Øm Kloster. En analyse af gravenes udsagn datering, udformning og personsammensætning. MA thesis, Aarhus University, Aarhus Afdeling for Middelalderarkæologi og Middelalder-arkæologisk nyhedsbrev, Højbjerg, 1999 